\title{
The susceptibility of SERPINE1 rs1799889 SNP in diabetic vascular complications: a meta-analysis of fifty-one case-control studies
}

JingYi Chen ${ }^{1,2 \dagger}$, ChuanNan Zhai ${ }^{3+}$, ZhiQian Wang ${ }^{4}$, Rui Li ${ }^{5}$, WenJing Wu², Kai Hou ${ }^{3}$, Mohammad Alzogool, ${ }^{1,2}$ Yan Wang ${ }^{1,2^{*}}$ and HongLiang Cong ${ }^{3^{*}}$

\begin{abstract}
Background: The serine protease inhibitor-1 (SERPINE1) rs1799889 single nucleotide polymorphism (SNP) has been constantly associated with diabetes mellitus (DM) and its vascular complications. The aim of this meta-analysis was to evaluate this association with combined evidences.

Methods: The systematic search was performed for studies published up to March 2021 which assess the associations between SERPINE1 rs1799889 SNP and the risks of DM, diabetic retinopathy (DR), diabetic cardiovascular disease (CVD) and diabetic nephropathy (DN). Only case-control studies were identified, and the linkage between SERPINE1 rs1799889 polymorphism and diabetic vascular risks were evaluated using genetic models.

Results: 51 comparisons were enrolled. The results revealed a significant association with diabetes risk in overall population (allelic: $\mathrm{OR}=1.34,95 \% \mathrm{Cl}=1.14-1.57$, homozygous: $\mathrm{OR}=1.66,95 \% \mathrm{Cl}=1.23-2.14$, heterozygous: $\mathrm{OR}=1.35$, $95 \% \mathrm{Cl}=1.08-1.69$, dominant: $\mathrm{OR}=1.49,95 \% \mathrm{Cl}=1.18-1.88$, recessive: $\mathrm{OR}=1.30,95 \% \mathrm{Cl}=1.06-1.59$ ) as well as in Asian descents (allelic: $\mathrm{OR}=1.45,95 \% \mathrm{Cl}=1.16-1.82$, homozygous: $\mathrm{OR}=1.88,95 \% \mathrm{Cl}=1.29-2.75$, heterozygous: $\mathrm{OR}=1.47,95 \% \mathrm{Cl}=1.08-2.00$, dominant: $\mathrm{OR}=1.64,95 \% \mathrm{Cl}=1.21-2.24$, recessive: $\mathrm{OR}=1.46,95 \% \mathrm{Cl}=1.09-1.96)$. $\mathrm{A}$ significant association was observed with $D R$ risk (homozygous: $O R=1.25,95 \% \mathrm{Cl}=1.01-1.56$, recessive: $\mathrm{OR}=1.20$, $95 \% \mathrm{Cl}=1.01-1.43$ ) for overall population, as for the European subgroup (homozygous: $\mathrm{OR}=1.32,95 \% \mathrm{Cl}=1.02-1.72$, recessive: $\mathrm{OR}=1.38,95 \% \mathrm{Cl}=1.11-1.71)$. A significant association were shown with $\mathrm{DN}$ risk for overall population (allelic: $\mathrm{OR}=1.48,95 \% \mathrm{Cl}=1.15-1.90$, homozygous: $\mathrm{OR}=1.92,95 \% \mathrm{Cl}=1.26-2.95$, dominant: $\mathrm{OR}=1.41,95 \% \mathrm{Cl}=1.01-$ 1.97, recessive: $\mathrm{OR}=1.78,95 \% \mathrm{Cl}=1.27-2.51$ ) and for Asian subgroup (allelic: $\mathrm{OR}=1.70,95 \% \mathrm{Cl}=1.17-2.47$, homozygous: $\mathrm{OR}=2.46,95 \% \mathrm{Cl}=1.30-4.66$, recessive: $\mathrm{OR}=2.24,95 \% \mathrm{Cl}=1.40-3.59)$ after ethnicity stratification. No obvious association was implied with overall diabetic CVD risk in any genetic models, or after ethnicity stratification.
\end{abstract}

\footnotetext{
*Correspondence: wangyan7143@vip.sina.com; hl_cong@126.com

${ }^{\dagger}$ JingYi Chen and ChuanNan Zhai contributed equally to this work.

'School of Medicine, NanKai University, Weijin Road No. 94, Nankai District, 300071 Tianjin, China

${ }^{3}$ Department of Cardiology, Tianjin Chest Hospital, Taierzhuang south Road No. 291, Jinnan District, 300350 Tianjin, China

Full list of author information is available at the end of the article
}

(c) The Author(s). 2021 Open Access This article is licensed under a Creative Commons Attribution 4.0 International License, which permits use, sharing, adaptation, distribution and reproduction in any medium or format, as long as you give appropriate credit to the original author(s) and the source, provide a link to the Creative Commons licence, and indicate if changes were made. The images or other third party material in this article are included in the article's Creative Commons licence, unless indicated otherwise in a credit line to the material. If material is not included in the article's Creative Commons licence and your intended use is not permitted by statutory regulation or exceeds the permitted use, you will need to obtain permission directly from the copyright holder. To view a copy of this licence, visit http://creativecommons.org/licenses/by/4.0/ The Creative Commons Public Domain Dedication waiver (http://creativecommons.org/publicdomain/zero/1.0/) applies to the data made available in this article, unless otherwise stated in a credit line to the data. 
Conclusions: SERPINE1 rs1799889 4G polymorphism may outstand for serving as a genetic synergistic factor in overall DM and DN populations, positively for individuals with Asian descent. The association of SERPINE1 rs1799889 SNP and DR or diabetic CVD risks was not revealed.

Keywords: SERPINE1, rs1799889, 4G/5G polymorphism, Plasminogen activator inhibitor 1, Diabetes, Diabetic vascular disease

\section{Background}

Diabetes mellitus (DM) is a major worldwide epidemic that has gained significant public attention. According to recent data from the latest WHO report on diabetes, its world prevalence has been estimated at $8.4 \%$ [1]. Added to this universal health issue, patients with diabetes often develop several vascular and neurogenic complications such as nephropathy, coronary heart disease, myocardial infarction, ischemic stroke, retinopathy, and neuropathy [2]. Most diabetic patients suffer from at least one complication, and vascular complications have become the leading cause of morbidity and mortality, while neurogenic complications such as retinopathy can severely affect quality of life [3].

To date, advances in epidemiological and pathophysiological research on DM have improved our understanding of the underlying pathogenic mechanism of diabetes. The determinants of DM consist of a matrix of genetic susceptibility and epigenetic and lifestyle factors that interact with one another and operate within the larger physical-sociocultural environment [2, 4]. Genetic elements are essentially involved in the pathogenesis of diabetes [5]. Plasminogen activator inhibitor 1 (PAI-1) belongs to the serine protease inhibitor (SERPINE) superfamily and plays a substantial role in the modulation of fibrinolysis and thrombosis [6]. The SERPINE1 gene is commonly recognized in the literature as PAI-1 gene and has been widely studied in epidemiologic studies. A common promoter SNPrs1799889 consists in an $A>G$ substitution located $2 \mathrm{~KB}$ upstream the SERPINE1 gene. The 4G allele in the promoter region at nucleotide position-675 is associated with higher PAI-1 levels compared to the 5G allele [7]. PAI-1 levels increase in the pre-diabetic as well as the diabetic state [8]. Moreover, increases in PAI-1 expression may contribute to vascular complications such as nephropathy, coronary heart disease, myocardial infarction, and ischemic stroke $[8,9]$.

To date, there have been extensive studies conducted investigating the potential role of SERPINE1 rs1799889 polymorphism in DM and subsequent complications. However, former meta-analyses reached inconsistent conclusions on this topic as they might be restrained by sample sizes or an insufficiency of studies [10, 11]. Contradictory as the previous results might be, recent investigations by $\mathrm{Li}$ et al. [12] and Xu et al. [13] defined the SERPINE1 rs1799889 SNP genotype dominant allele model as a risk factor for vascular complications in patients with DM. As a result, we felt obliged to perform the updated meta-analysis with larger sample sizes and more sufficient data, intending to better solve the disparity and further evaluate the associations between SERPINE1 rs1799889 SNP polymorphism and DM vascular complications.

\section{Method}

\section{Search strategy}

The current meta-analysis was performed according to the Preferred Reporting Items for Systematic Reviews and Meta-Analyses (PRISMA) statement [14]. Potentially related articles were systematically searched in PubMed, Medline, Embase, CNKI, OVID, ScienceDirect and WanFang to identify published literatures up to March 2021 using the following key words: "diabetes mellitus (DM)", "diabetes", "diabetic", and "plasminogen activator inhibitor-1", "PAI-1", "PAI 1", "SERPINE1", "polymorphism, genetic", "polymorphism, single-stranded conformational", "polymorphism, single nucleotide", "polymorphism, restriction fragment length", "variants", "variations, DNA copy number", "genotype", "allele", "mutation", "mutation, frameshift", "INDEL mutation", "rs1799889", “4G", "5G", “4G/ $5 \mathrm{G}$ ", and "diabetes complications", "coronary artery/heart disease (CAD/CHD)", "cardiovascular disease (CVD)", "myocardial infarction", "ischemic heart disease", "ischemic stroke", or "nephropathy", "renal disease", or "retinopathy", "diabetic retinopathy", "retinal artery occlusion". No language restrictions were imposed in this meta-analysis. Furthermore, the reference lists of all retrieved articles were screened to identify potentially relevant studies. The literature search was independently performed by two reviewers (JY Chen and CN Zhai).

\section{Inclusion and exclusion criteria}

A study included in this meta-analysis must meet with the following criteria: (1) case-control study on correlation analysis between SERPINE1 rs1799889 SNP and the risk of diabetes and associated complications to be assessed; (2) the study must include original and adequate data to allow calculation of odds ratios (ORs) with $95 \%$ confidence intervals (CIs) (independence among studies); (3) evaluation of SERPINE1 rs1799889 polymorphism and the risk of diabetes and its complications.

A study was excluded when fulfilling one of the following criteria: (1) for overlapping-data study, only the most recent 
and complete one was enrolled; (2) study with missing information (particularly genotype distributions), while the required information could not be acquired from the corresponding author; (3) genome scans investigating linkages with no detailed genotype frequencies between cases and controls. If inclusions have disagreements, we reached a consensus through discussion. Two reviewers (JY Chen and CN Zhai) independently screened the titles and abstracts for the eligibility criteria. Subsequently, reviewers both read the full text of the studies which potentially met with the inclusion criteria, and the literature was reviewed to determine final inclusive data.

\section{Data extraction}

Two reviewers (JY Chen and CN Zhai) conducted the data extraction from each study independently. Any disagreement between the two reviewers was solved by discussion with the third reviewer (ZQ Wang) until reaching a consensus. Three reviewers (JY Chen, CN Zhai, and ZQ Wang) independently evaluated the quality of each casecontrol study by using the Newcastle-Ottawa Scale criteria [15]. We summarized the information extracted from each literature in Table 1. The characteristics of the selected studies included (1) name of first author; (2) year of publication; (3) country in which the study was done; (4) ethnicity; (5) the number of cases and controls; (6) the genotypic distributions of SERPINE1 rs1799889 polymorphisms in cases and controls; (7) type of disease and outcome. Furthermore, the probability value ( $P$ value) of Hardy-Weinberg equilibrium (HWE) test was also calculated on the basis of allele frequencies of certain SERPINE1 rs1799889 polymorphisms in the control group.

\section{Statistical analysis}

All statistical analyses were conducted using STATA 12.0 (Stata-corp, college station, Tex) and Review Manager Version 5.3.3 (The Cochrane Collaboration, Software Update, Oxford, United Kingdom). The associations between the SERPINE1 rs1799889 polymorphism and DM and its complications' susceptibility were assessed using the following genetic models: $4 \mathrm{G}$ vs. 5G (allelic), 4G4G vs. 5G5G (homozygous), 4G5G vs. 5G5G (heterozygous), 4G4G + 4G5G vs. 5G5G (dominant), and 4 G4G vs. 5 G5G + 5G4G (recessive). Between-study heterogeneity was tested using $\mathrm{Q}$ statistics, and $P<0.1$ was considered statistically significant. The Mantel-Haenszel method for fixed effects and the Der-Simonian and Laird method for random effects were used to estimate pooled effects [16]. We used fixed-effects methods if the result of the $\mathrm{Q}$ test was not significant. Otherwise, we calculated the pooled ORs and $95 \%$ CIs assuming a randomeffects model. Fixed effects assume that genetic factors have similar effects on disease susceptibility across all studies and that the observed variations between studies are caused by chance alone [17]. The random effects model assumes that different studies may have substantial diversity and assesses both within- and betweenstudy variations [18]. A recently developed measure, $\mathrm{I}^{2}$, was used to quantify the inconsistency among the studies' results with values of $50 \%$ or higher and the large heterogeneity for values of $75 \%$ or higher [19]. The data are shown as the ORs with $95 \%$ CIs, with two-tailed $P$-values; statistical significance was set at $P<0.05$ (two-tailed). Meta-regression analysis was applied to evaluate the heterogeneity of the studies. Publication bias was conducted statistically via Begg's and Egger's bias test, which measures the degree of funnel plot asymmetry [20, 21]. The Begg's adjusted rank correlation test was used to assess the correlation between test accuracy estimates and their variances. The Egger's bias test detects funnel plot asymmetry by determining whether the intercept deviates significantly from zero in a regression of the standardized effect estimates against their precision.

\section{Results}

Search results and characteristics of included studies

The study flow chart is summarized in Fig. 1, the primary literature search identified 208 potentially relevant articles. After exclusion of duplicate or irrelevant articles by reading titles and abstracts, and screening through study results, 50 articles were retrieved for further investigation. Another 15 articles were excluded subsequently after full text evaluation. Finally, a total of 35 studies with 51 comparisons containing 15,341 subjects that met our inclusion and exclusion criteria were included $[12,13,22-54]$. The quality of observational studies is presented in Supplementary Material. All of the studies included in the meta-analysis had high quality in their data outcome and clinical design. Characteristics of included studies were summarized in Table 1.

\section{Association of SERPINE1 rs1799889 SNP with overall diabetes risk}

In overall population, our meta-analysis revealed a significant association between the SERPINE1 rs1799889 polymorphism and overall diabetes risk, in allelic (4G vs. 5G: $\mathrm{OR}=1.34,95 \% \mathrm{CI}=1.14-1.57, \mathrm{p}=0.00$ ), homozygous (4G4G vs. 5G5G: $\mathrm{OR}=1.66,95 \% \mathrm{CI}=1.23-2.14, \mathrm{p}=0.00$ ), heterozygous (4G5G vs. 5G5G: $\mathrm{OR}=1.35,95 \% \mathrm{CI}=1.08$ 1.69, $\mathrm{p}=0.00)$, dominant $(4 \mathrm{G} 4 \mathrm{G}+4 \mathrm{G} 5 \mathrm{G}$ vs. $5 \mathrm{G} 5 \mathrm{G}: \mathrm{OR}=$ $1.49,95 \% \mathrm{CI}=1.18-1.88, \mathrm{p}=0.00$ ), and recessive ( $4 \mathrm{G} 4 \mathrm{G}$ vs. $5 \mathrm{G} 5 \mathrm{G}+5 \mathrm{G} 4 \mathrm{G}: \quad \mathrm{OR}=1.30,95 \% \mathrm{CI}=1.06-1.59, \mathrm{p}=0.01)$ models. When analyses were subdivided by ethnicity, no obvious associations were noted for the European using any of the five genetic models. For the Asian subgroup, significant associations were observed in all of the five genetic models (allelic: $\mathrm{OR}=1.45,95 \% \mathrm{CI}=1.16-1.82, \mathrm{p}=0.00$; 
Table 1 Characteristics and genotype frequencies for the SERPINE1 rs1799889 SNP in the included studies

\begin{tabular}{|c|c|c|c|c|c|c|c|c|c|c|c|}
\hline \multirow{2}{*}{$\begin{array}{l}\text { Study } \\
\text { Mansfield et al }\end{array}$} & \multirow{2}{*}{$\begin{array}{l}\text { Year } \\
1995\end{array}$} & \multirow{2}{*}{$\begin{array}{l}\text { Country } \\
\text { UK }\end{array}$} & \multirow{2}{*}{$\begin{array}{l}\text { Ethnicity } \\
\text { European }\end{array}$} & \multicolumn{2}{|c|}{$\begin{array}{l}\text { Sample } \\
\text { size Case/ } \\
\text { Control }\end{array}$} & \multirow{2}{*}{$\begin{array}{l}\text { Study type } \\
\text { Hospital based }\end{array}$} & \multirow{2}{*}{$\begin{array}{l}\text { Outcomes } \\
\text { CAD \& NIDDM }\end{array}$} & \multirow{2}{*}{$\begin{array}{l}\begin{array}{l}\text { Genotyping } \\
\text { methods }\end{array} \\
P C R\end{array}$} & \multicolumn{2}{|c|}{$\begin{array}{l}5 \mathrm{G} \text { allele frequency } \\
\text { Case/Control (\%) }\end{array}$} & \multirow{2}{*}{$\begin{array}{l}\text { HWE } \\
Y\end{array}$} \\
\hline & & & & 38 & 122 & & & & 27.6 & 42.2 & \\
\hline Nagi et al & 1997 & USA & Mix & 70 & 101 & Population based & DR \& NIDDM & PCR & 48.6 & 60.3 & Y \\
\hline Broch et al & 1998 & Spain & European & 82 & 95 & Hospital based & DR \& NIDDM & PCR & 51.2 & 54.7 & Y \\
\hline \multirow[t]{3}{*}{ Kimura et al } & 1998 & Japan & Asian & 208 & 177 & Population based & NIDDM & PCR & 41.3 & 40.1 & Y \\
\hline & & & & 110 & 98 & Population based & PDR \& NIDDM & PCR & 42.7 & 39.8 & Y \\
\hline & & & & 110 & 98 & Population based & DN \& NIDDM & PCR & 41.8 & 40.9 & Y \\
\hline \multirow[t]{2}{*}{ De Cosmo et al } & 1999 & Italy \& UK & European & 311 & 200 & Population based & IDDM & PCR & 48.6 & 49.0 & Y \\
\hline & & & & 175 & 136 & Population based & DN \& IDDM & PCR & 47.1 & 50.4 & Y \\
\hline \multirow[t]{2}{*}{ Wong et a } & 2000 & Hong Kong & Asian & 84 & 57 & Hospital based & DR \& NIDDM & PCR & 40.5 & 47.4 & Y \\
\hline & & & & 95 & 46 & Hospital based & DN \& NIDDM & PCR & 39.5 & 51.1 & Y \\
\hline Tarnow et al & 2000 & Denmark & European & 197 & 191 & Hospital based & DN \& IDDM & PCR & 46.2 & 46.1 & Y \\
\hline \multirow[t]{2}{*}{ Ding et al } & 2001 & China & Asian & 112 & 169 & Hospital based & NIDDM & PCR & 56.3 & 67.2 & Y \\
\hline & & & & 49 & 63 & Hospital based & CHD \& NIDDM & PCR & 54.9 & 64.3 & Y \\
\hline \multirow[t]{2}{*}{ Li et al } & 2001 & China & Asian & 143 & 85 & Hospital based & NIDDM & $P C R$ & 41.3 & 44.7 & Y \\
\hline & & & & 79 & 64 & Hospital based & DN \& NIDDM & PCR & 39.2 & 43.8 & Y \\
\hline Petrovic et al & 2003 & Slovenia & European & 154 & 194 & Population based & MI \& NIDDM & PCR & 46.8 & 42.0 & Y \\
\hline Santos et al & 2003 & Brazil & European & 99 & 111 & Hospital based & DR \& NIDDM & PCR & 55.1 & 53.6 & Y \\
\hline Globocnik-P et al & 2003 & Slovenia & European & 124 & 80 & Hospital based & DR \& NIDDM & PCR & 45.2 & 43.8 & Y \\
\hline Lopes et al & 2003 & France & European & 229 & 406 & Population based & CHD \& NIDDM & PCR & 44.1 & 48.9 & Y \\
\hline \multirow[t]{3}{*}{ Liu et al } & 2004 & China & Asian & 147 & 26 & Hospital based & NIDDM & PCR & 45.9 & 53.8 & Y \\
\hline & & & & 56 & 91 & Hospital based & DR \& NIDDM & PCR & 50.0 & 43.4 & Y \\
\hline & & & & 77 & 70 & Hospital based & DN \& NIDDM & PCR & 42.9 & 49.3 & Y \\
\hline Pan et al & 2004 & China & Asian & 204 & 60 & Hospital based & NIDDM & PCR & 52.7 & 56.7 & Y \\
\hline Li et al & 2004 & China & Asian & 54 & 54 & Population based & NIDDM & PCR & 42.6 & 46.3 & Y \\
\hline Murata et al & 2004 & Japan & Asian & 188 & 92 & Hospital based & DR \& NIDDM & PCR & 35.6 & 34.2 & Y \\
\hline \multirow[t]{2}{*}{ Tang et al } & 2004 & China & Asian & 108 & 38 & Hospital based & NIDDM & PCR & 38.9 & 46.1 & Y \\
\hline & & & & 59 & 49 & & DN \& NIDDM & PCR & 31.4 & 48.0 & Y \\
\hline \multirow[t]{2}{*}{ Wang et al } & 2004 & China & Asian & 114 & 30 & Hospital based & NIDDM & PCR & 34.6 & 61.7 & Y \\
\hline & & & & 76 & 38 & Hospital based & DN \& NIDDM & $P C R$ & 28.3 & 47.4 & Y \\
\hline Meigs et al & 2006 & USA & European & 216 & 1953 & Population based & DM & PCR & 46.1 & 47.4 & Y \\
\hline \multirow[t]{2}{*}{ Zietz et al } & 2006 & Germany & European & 192 & 312 & Population based & DR \& NIDDM & $P C R$ & 42.4 & 44.4 & Y \\
\hline & & & & 189 & 320 & Population based & CHD \& NIDDM & PCR & 45.8 & 42.7 & Y \\
\hline Martin et al & 2007 & Ireland & European & 222 & 361 & Hospital based & DN \& IDDM & PCR & 42.8 & 44.5 & Y \\
\hline \multirow[t]{2}{*}{ Zheng et al } & 2007 & China & Asian & 247 & 87 & Hospital based & NIDDM & PCR & 44.3 & 46.0 & Y \\
\hline & & & & 167 & 80 & Hospital based & DN \& NIDDM & PCR & 40.7 & 51.9 & Y \\
\hline Saely et al & 2008 & Austria & European & 148 & 524 & Population based & NIDDM & PCR & 43.9 & 47.6 & Y \\
\hline Yan et al 1 & 2008 & China & Asian & 66 & 33 & Hospital based & NIDDM & PCR & 50.8 & 56.1 & Y \\
\hline \multirow[t]{2}{*}{ Yan et al 2} & 2008 & China & Asian & 217 & 58 & Population based & NIDDM & PCR & 53.9 & 79.3 & Y \\
\hline & & & & 125 & 92 & Population based & DN \& NIDDM & PCR & 42.4 & 69.6 & Y \\
\hline Ezzidi et al & 2009 & Tunisia & European & 383 & 473 & Hospital based & DR \& NIDDM & PCR & 58.1 & 63.0 & Y \\
\hline Prasad et al & 2010 & India & Mix & 196 & 225 & Hospital based & DN \& NIDDM & PCR & 48.0 & 50.9 & Y \\
\hline Xue et al & 2010 & China & Asian & 120 & 50 & Hospital based & NIDDM & PCR & 41.7 & 70.0 & Y \\
\hline & & & & 70 & 50 & Hospital based & DN \& NIDDM & PCR & 20.7 & 71.0 & Y \\
\hline
\end{tabular}


Table 1 Characteristics and genotype frequencies for the SERPINE1 rs1799889 SNP in the included studies (Continued)

\begin{tabular}{|c|c|c|c|c|c|c|c|c|c|c|c|}
\hline \multirow{3}{*}{$\begin{array}{l}\text { Study } \\
\text { Liu et al }\end{array}$} & \multirow{3}{*}{$\begin{array}{l}\text { Year } \\
2011\end{array}$} & \multirow{3}{*}{$\begin{array}{l}\text { Country } \\
\text { China }\end{array}$} & \multirow{3}{*}{$\begin{array}{l}\text { Ethnicity } \\
\text { Asian }\end{array}$} & \multirow{2}{*}{\multicolumn{2}{|c|}{$\begin{array}{l}\text { Sample } \\
\text { size Case/ } \\
\text { Control }\end{array}$}} & \multirow{3}{*}{$\begin{array}{l}\text { Study type } \\
\text { Hospital based }\end{array}$} & \multirow{3}{*}{$\begin{array}{l}\text { Outcomes } \\
\text { NIDDM }\end{array}$} & \multirow{3}{*}{$\begin{array}{l}\begin{array}{l}\text { Genotyping } \\
\text { methods }\end{array} \\
P C R\end{array}$} & \multirow{2}{*}{\multicolumn{2}{|c|}{$\frac{5 \mathrm{G} \text { allele frequency }}{\text { Case/Control (\%) }}$}} & \multirow{3}{*}{$\begin{array}{l}\text { HWE } \\
Y\end{array}$} \\
\hline & & & & & & & & & & & \\
\hline & & & & 63 & 39 & & & & 39.7 & 57.7 & \\
\hline & & & & 29 & 34 & Hospital based & DN \& NIDDM & $P C R$ & 44.8 & 35.3 & Y \\
\hline Tan et al & 2011 & China & Asian & 30 & 50 & Hospital based & CHD \& NIDDM & PCR & 35.0 & 48.0 & Y \\
\hline Al-Hamodi et al & 2012 & Malaysia & Asian & 303 & 131 & Population based & NIDDM & $P C R$ & 50.0 & 53.1 & Y \\
\hline Weng et al & 2012 & Taiwan & Asian & 27 & 251 & Hospital based & PTDM & PCR & 53.7 & 40.0 & Y \\
\hline Xu et al & 2016 & China & Asian & 107 & 101 & Hospital based & NIDDM & PCR & 37.9 & 47.0 & Y \\
\hline & & & & 65 & 42 & Hospital based & DN \& NIDDM & PCR & 37.7 & 38.1 & Y \\
\hline Li et al & 2018 & China & Asian & 175 & 125 & Hospital based & IS \& NIDDM & PCR & 42.6 & 36.8 & Y \\
\hline
\end{tabular}

CAD coronary artery disease, $C H D$ coronary heart disease, $M I$ myocardial infarction, IS ischemic stroke, IDDM insulin-dependent diabetes mellitus, NIDDM noninsulin-dependent diabetes mellitus, PTDM post-transplant diabetes mellitus, $P C R$ polymerase chain reaction, HWE Hardy-Weinberg equilibrium, $Y$ Yes

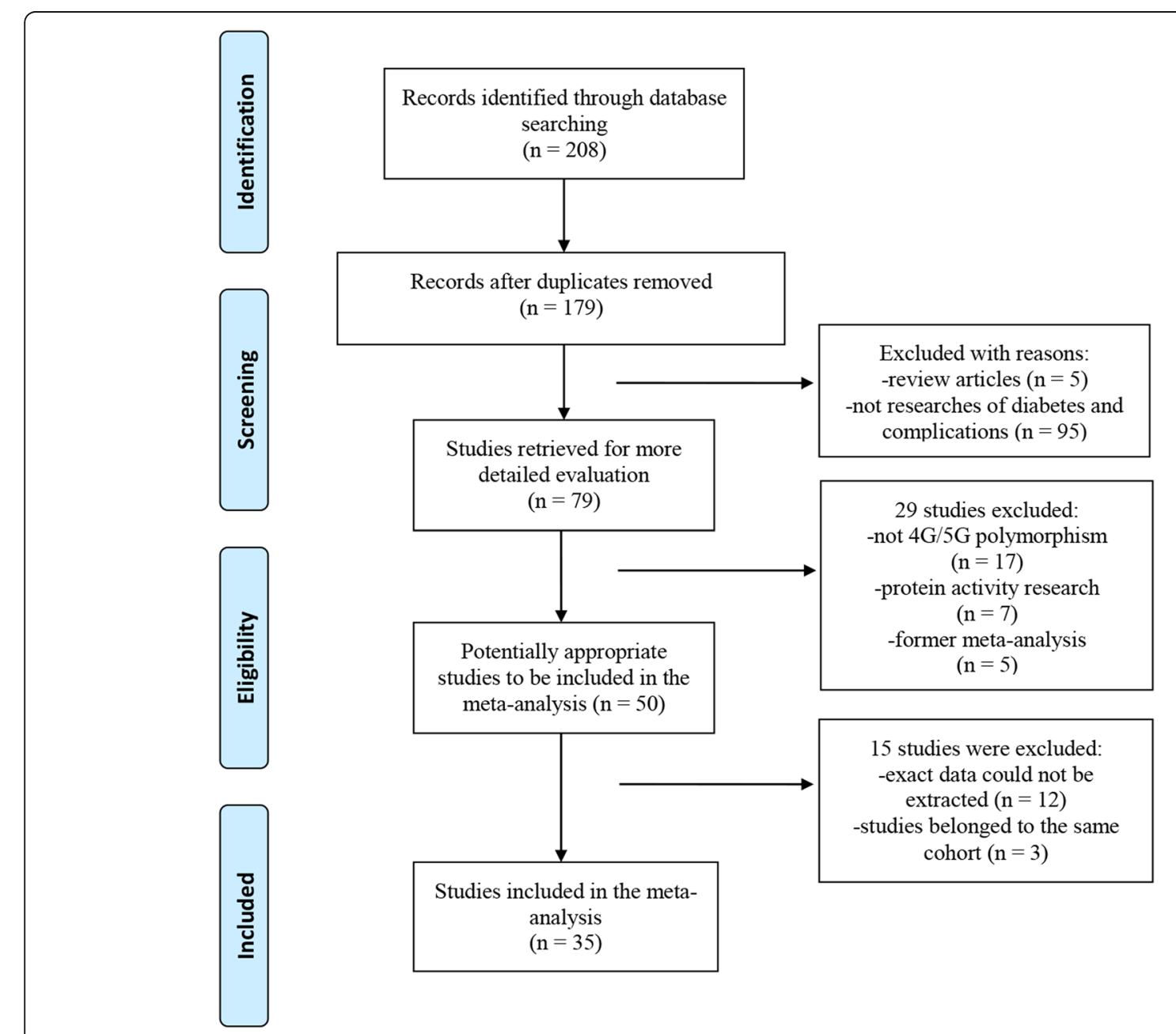

Fig. 1 Flow of studies for meta-analysis 
homozygous: $\mathrm{OR}=1.88,95 \% \mathrm{CI}=1.29-2.75, \mathrm{p}=0.00$; heterozygous: $\mathrm{OR}=1.47,95 \% \mathrm{CI}=1.08-2.00, \mathrm{p}=0.01$; dominant: $\mathrm{OR}=1.64,95 \% \mathrm{CI}=1.21-2.24, \mathrm{p}=0.00$; recessive: $\mathrm{OR}=1.46,95 \% \mathrm{CI}=1.09-1.96, \mathrm{p}=0.01)$. Results of pooled analyses are summarized and presented in Table 2; Fig. 2.

\section{Association of SERPINE1 rs1799889 SNP with DR risk}

In overall population, a significant association between the SERPINE1 rs1799889 polymorphism and DR risk was observed in homozygous (4G4G vs. 5G5G: OR= $1.25,95 \% \mathrm{CI}=1.01-1.56, \mathrm{p}=0.04)$ and recessive (4G4G vs. $5 \mathrm{G} 5 \mathrm{G}+5 \mathrm{G} 4 \mathrm{G}$ : $\mathrm{OR}=1.20,95 \% \mathrm{CI}=1.01-1.43, \mathrm{p}=$ 0.04) models, but no association was found in the other three genetic models. For the European subgroup, a significant association was revealed by homozygous $(\mathrm{OR}=$ 1.32, $95 \% \mathrm{CI}=1.02-1.72, \mathrm{p}=0.04)$ and recessive model $(\mathrm{OR}=1.38,95 \% \mathrm{CI}=1.11-1.71, p<0.01)$, but no association was observed in the allelic, heterozygote, and dominant models. No significant associations were indicated among Asian descent in all genetic models. Results of pooled analyses are summarized and presented in Table 3; Fig. 3.

\section{Association of SERPINE1 rs1799889 SNP with diabetic CVD risk}

No significant association was implied between the SERPINE1 rs1799889 polymorphism and overall diabetic CVD risk in any genetic models. Additionally, after ethnicity stratification, no significant association was revealed either in European or Asian descent. Results of pooled analyses are summarized and presented in Table 4; Fig. 4.

\section{Association of SERPINE1 rs1799889 SNP with DN risk}

In overall population, significant associations were shown between the SERPINE1 rs1799889 polymorphism and overall diabetic nephropathy risk, in allelic (4G vs. 5G: $\mathrm{OR}=1.48,95 \% \mathrm{CI}=1.15-1.90, \mathrm{p}=0.00)$, homozygous (4G4G vs. $5 \mathrm{G} 5 \mathrm{G}: \mathrm{OR}=1.92,95 \% \mathrm{CI}=1.26-2.95, \mathrm{p}=$ 0.00 ), dominant (4G4G + 4G5G vs. $5 \mathrm{G} 5 \mathrm{G}$ : $\mathrm{OR}=1.41,95 \%$ $\mathrm{CI}=1.01-1.97, \mathrm{p}=0.04)$, and recessive $(4 \mathrm{G} 4 \mathrm{G}$ vs. $5 \mathrm{G} 5 \mathrm{G}+$ 5G4G: $\mathrm{OR}=1.78,95 \% \mathrm{CI}=1.27-2.51, \mathrm{p}=0.00)$ models. After subdivided by ethnicity, remarkable associations were observed in allelic $(\mathrm{OR}=1.70,95 \% \mathrm{CI}=1.17-2.47$, $\mathrm{p}=0.01)$, homozygous $(\mathrm{OR}=2.46,95 \% \mathrm{CI}=1.30-4.66$, $\mathrm{p}=0.01)$, and recessive $(\mathrm{OR}=2.24,95 \% \mathrm{CI}=1.40-3.59$, $\mathrm{p}=0.00$ ) models for Asian subgroup. On the contrary, no obvious associations were noted for the European using any of the five genetic models. Results of pooled analyses are summarized and presented in Table 5; Fig. 5.

\section{Meta-regression analysis}

A meta-regression analysis for the discovery of potential origins of heterogeneity, such as study type, published years, sample sizes, age, gender, ethnicity and outcomes, was conducted. Single covariates were added in the allelic, homozygous, heterozygous, dominant and recessive models. However, the results of meta-regression indicated that none of the above sources contributed to the heterogeneity across all studies of the association between SERPINE1 rs1799889 polymorphism and diabetic vascular susceptibility, since all the $p$ values calculated were larger than 0.05 .

\section{Sensitivity analysis and publication bias}

Sensitivity analysis with stratified analyses were conducted to examine the stability of our meta-analysis results. The high heterogeneity in some of the genetic models was obvious among studies except for the association with DR risk. On the association with DM and DN risk, a heterogeneity was detected within the overall analysis for the allelic model. On the association with DM, $\mathrm{DR}$ and DN risks, the heterogeneity in any genetic model was not significantly varied after either sensitivity analysis or sub-group analysis by ethnicity stratification. On the association with diabetic CVD risk, heterogeneity was noted for allelic/homozygote/recessive models, except for the European sub-group. After the sensitivity analysis, the study from $\mathrm{Li}$ et al. [12] were mainly responsible for the observed heterogeneity.

Potential publication bias in the current study was evaluated with Begg's and Egger's bias test. Publication bias was noted within DM sub-group with Egger test and DN sub-group for recessive model. Except for that, no obvious publication bias was observed in other comparisons, which confirmed that the results our metaanalysis presented were statistically robust (Table 6).

\section{Discussion}

The current meta-analysis suggests that the SERPINE1 rs1799889 4G polymorphism possesses a genetic modulatory function in overall DM populations and in diabetic renal vascular complications, which can be ethnically divergent according to the results. Genetic factors have long been considered a substantial determinant within the diabetic physical-sociocultural environment [55]. Positive family history might attribute a 2- to 4-fold increase in risk for diabetes [56]. The DCCT (Diabetes Control and Complications Trial) [57] and the EDIC (Epidemiology of Diabetes Interventions and Complications) [58] established that hyperglycemia is modified by both genetic determinants of individual susceptibility and by independent accelerating factors. Recently, largescale genome wide association studies (GWAS) [59, 60] have identified hundreds of genetic risk variants, which in aggregate could explain the substantial role of genetic predisposition in DM. Additionally, one recent exome sequencing study [61] discovered additional genes and 


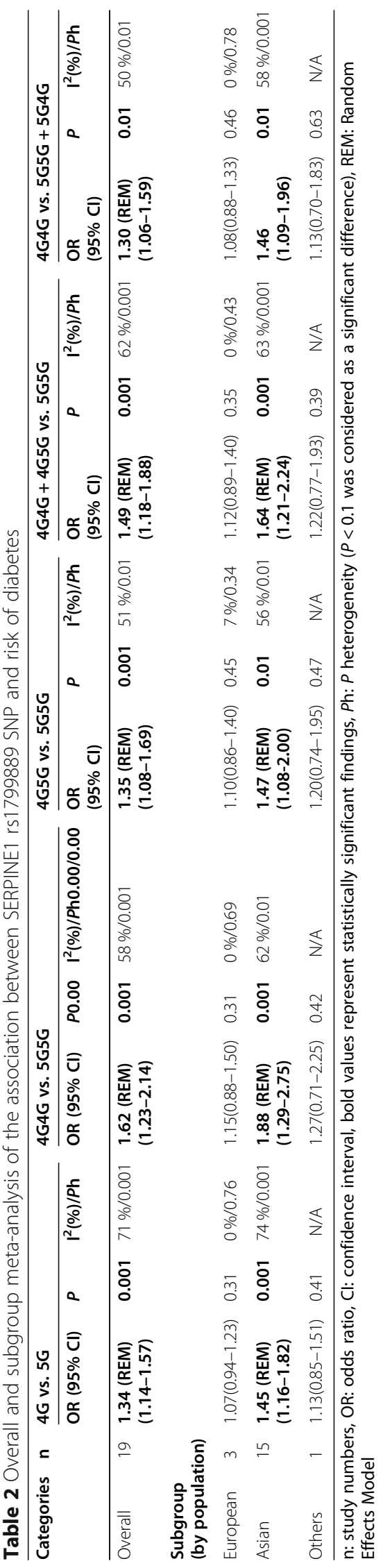




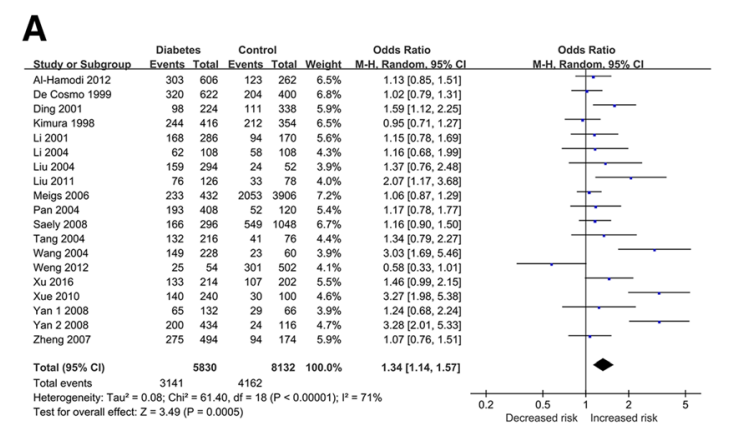

B

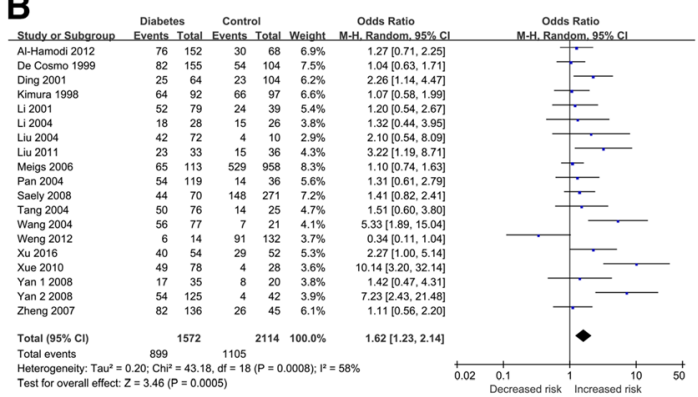

C
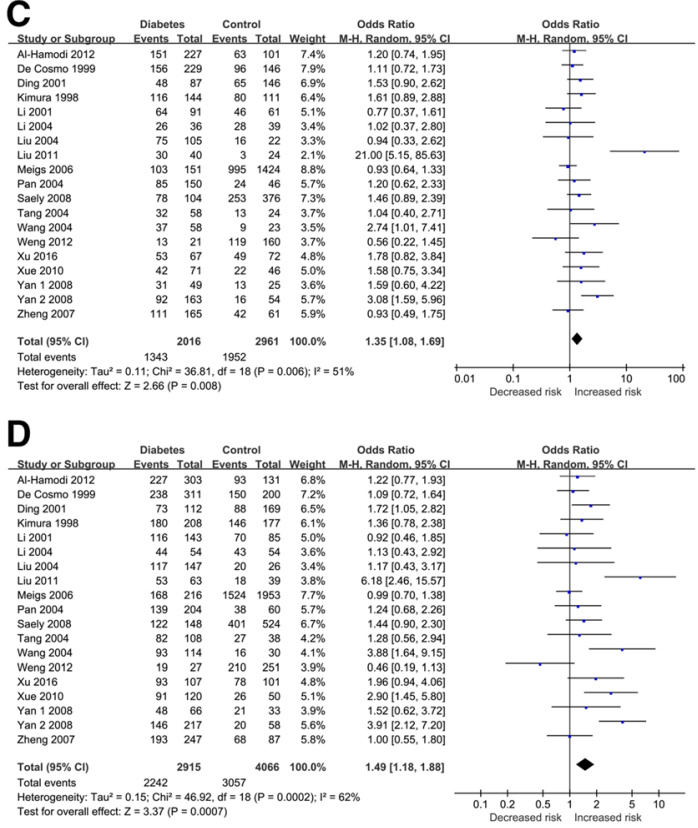

E

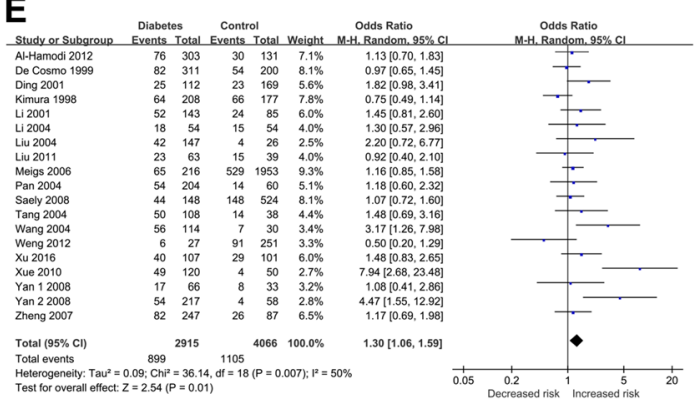

Fig. 2 Forest plots of the association between SERPINE1 rs1799889 SNP and diabetes risk. (A) allelic model, (B) homozygote model, (C) heterozygote model, (D) dominant model, and (E) recessive model pathways for future target gene prioritization efforts and complications in DM [60]. Overall, the evidence jointly supports the theory that genetic factors significantly account for the pathogenesis of DM and its complications.

PAI-1 is a serine protease inhibitor protein encoded by the SERPINE1 gene that plays an important role in regulating fibrinolysis and thrombosis by inhibiting the activity of tissue plasminogen activator and urokinase plasminogen activator, whose activation is driven by tissue-type plasminogen activator (tPA) cleavage of plasminogen [62]. Previous human and animal PAI-1 studies have confirmed its effect on hemostasis and thrombolysis, where suppressing PAI-1 activity would resulted in a reduction of thrombus formation while activation of the PAI-1 promoted thrombus formation [63]. Classic studies have confirmed that high plasma levels of PAI-1 are associated with an increased risk of cardiovascular diseases [64, 65], and SERPINE1 allelic variations are also associated with the pathogenesis of metabolic syndrome, insulin resistance, and diabetes [66-68]. To date, several SERPINE1 polymorphisms have been identified, of which the SERPINE1 rs1799889-4G/5G insertiondeletion variant has been most consistently implicated with the plasma level of PAI-1 [68]. Unlike the 5G allele, which binds a transcription repressor protein resulting in low PAI-1 expression, the 4G allele does not bind a transcription repressor, thus conferring a "high PAI-1 expressor" nature to the allele [9]. In diabetic populations, PAI-1 levels are particularly connected to elevated fasting insulin levels and triglycerides, and inhibition of PAI-1 may have merit in patients at high cardiovascular risk [69].

Previous studies of the distribution of the SERPINE1 rs1799889 SNP have been controversial concerning the susceptibility of diabetes among various populations. Saely et al. [37] demonstrated no significant difference in the SERPINE1 4G/5G polymorphism between nondiabetic control subjects and diabetic patients. In contrast, Al-Hamodi et al. [41] suggested that the dominant and additive models showed a weak association with T2DM. Nagi et al. [23] reported preliminary findings indicating that in Pima Indians with type 2 diabetes, the presence of the 4G allele was associated with a higher risk of diabetic retinopathy. However, Santos et al. [34] indicated that the $4 \mathrm{G} / 5 \mathrm{G}$ polymorphism was not related to the presence of DR in Euro-Brazilian patients. While Ezzidi et al. [40] identified that genetic variations served as risk factors for DR but not DR severity. Tarnow et al. [46] suggested that the SERPINE1 4G/5G polymorphism might not contribute to the genetic susceptibility to diabetic nephropathy or retinopathy. In contrast, Prasad et al. [48] and Xu et al. [13] demonstrated major associations with the SERPINE1 rs1799889 4G polymorphism and the progression of diabetic nephropathy. Mansfield 


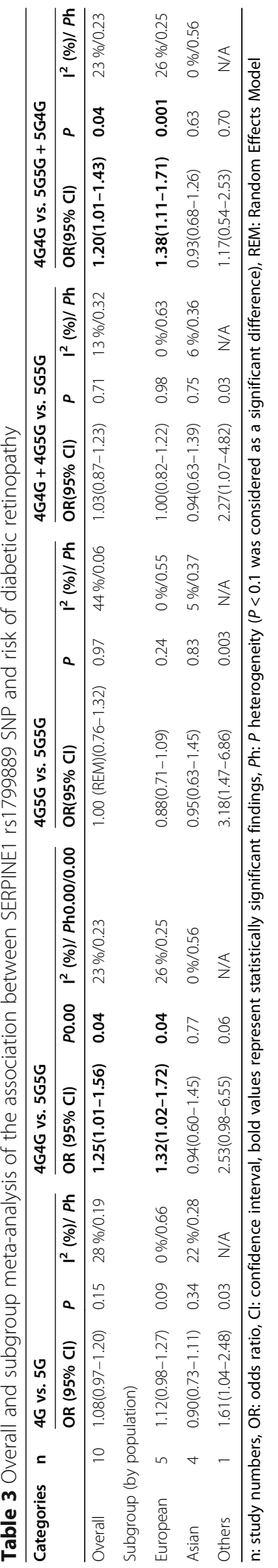




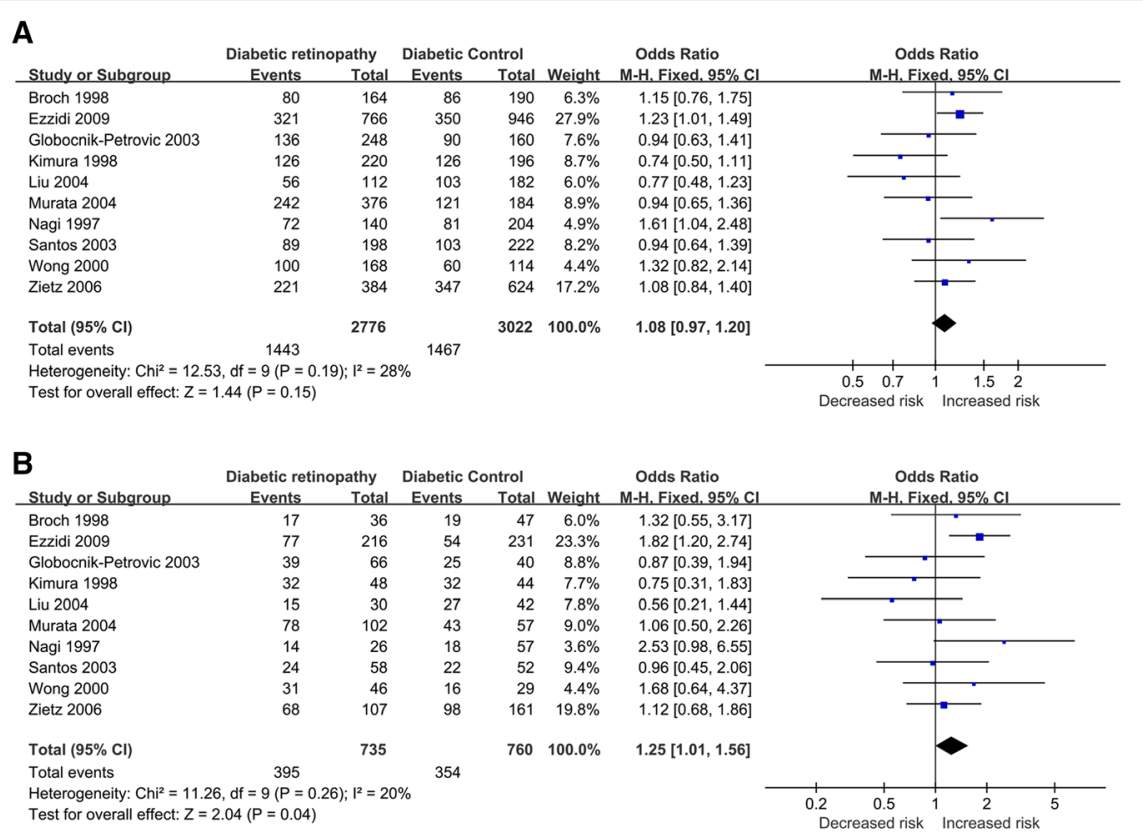

C
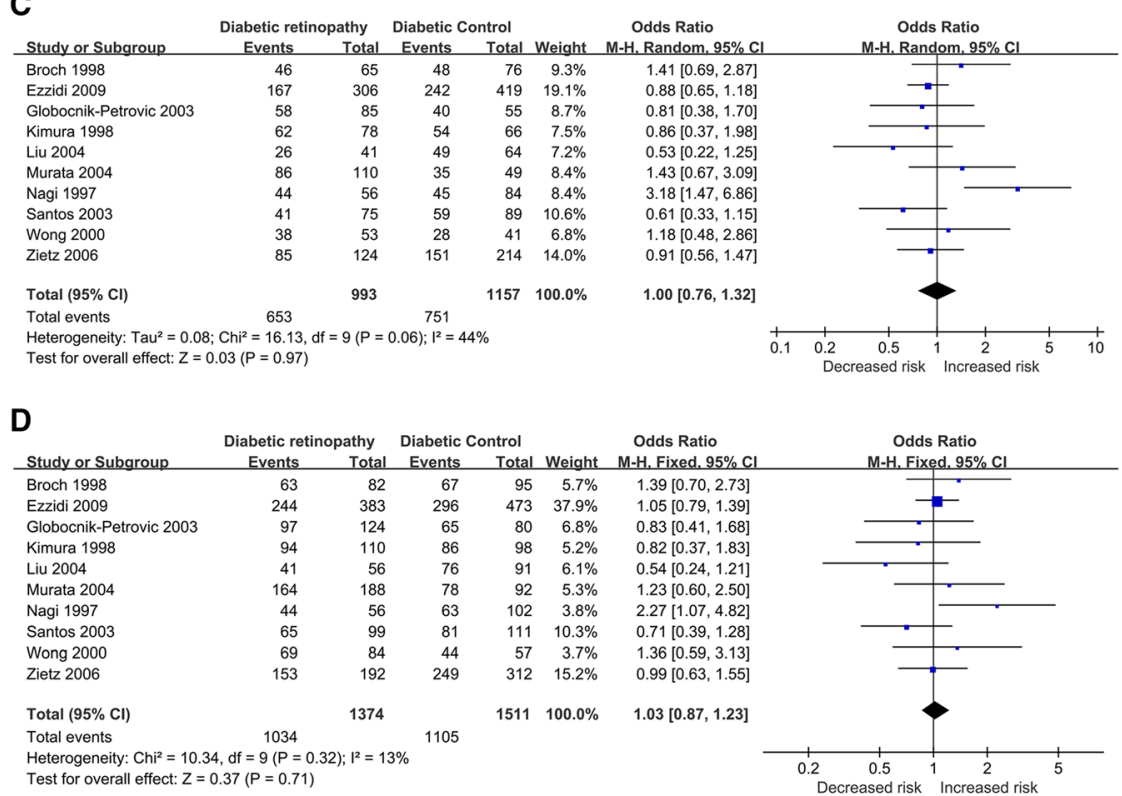

E

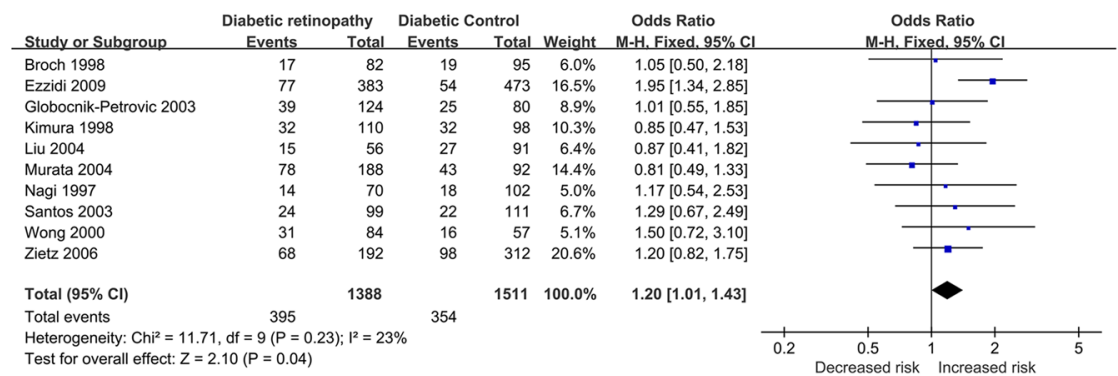

Fig. 3 Forest plots of the association between SERPINE1 rs1799889 SNP and DR risk. (A) allelic model, (B) homozygote model, (C) heterozygote model, (D) dominant model, and (E) recessive model (DR: diabetic retinopathy) 


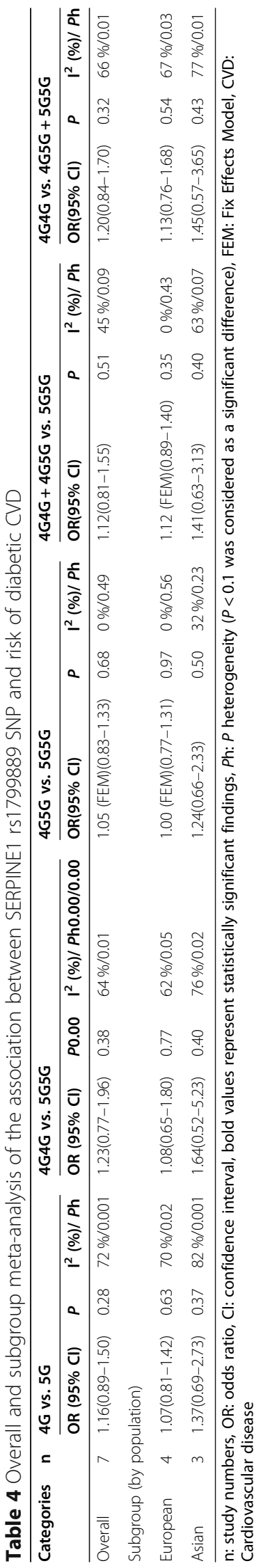




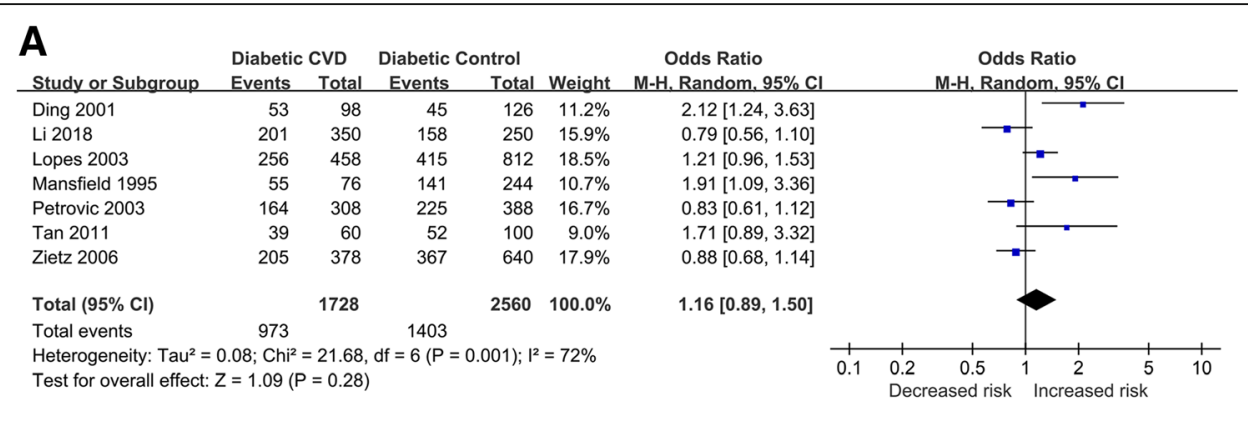

B

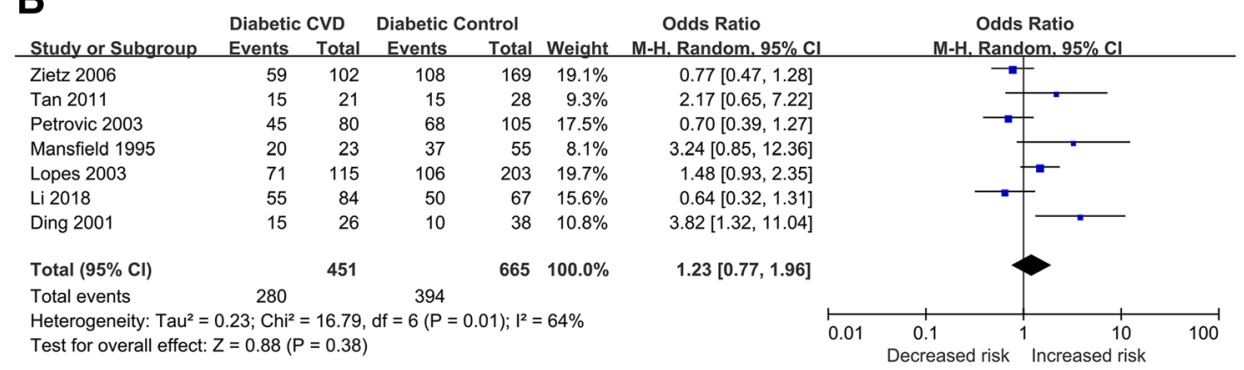

\section{C}

Diabetic CVD Diabetic Control Odds Ratio Odds Ratio

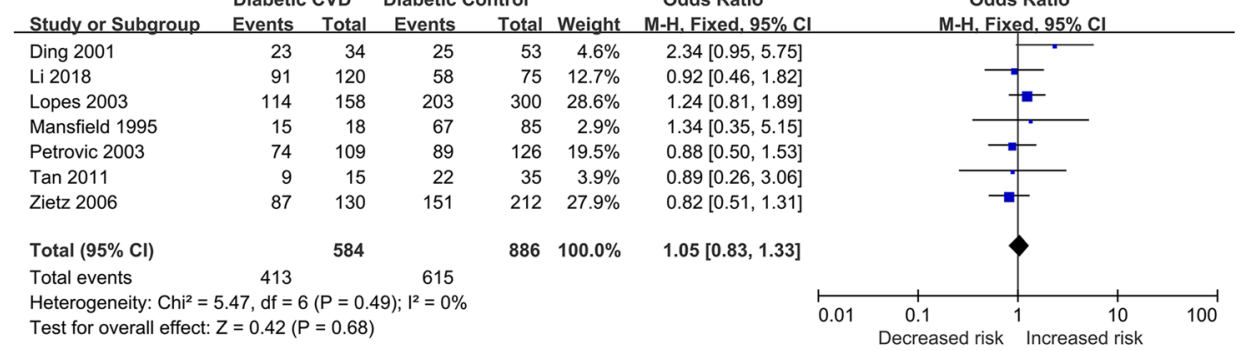

D

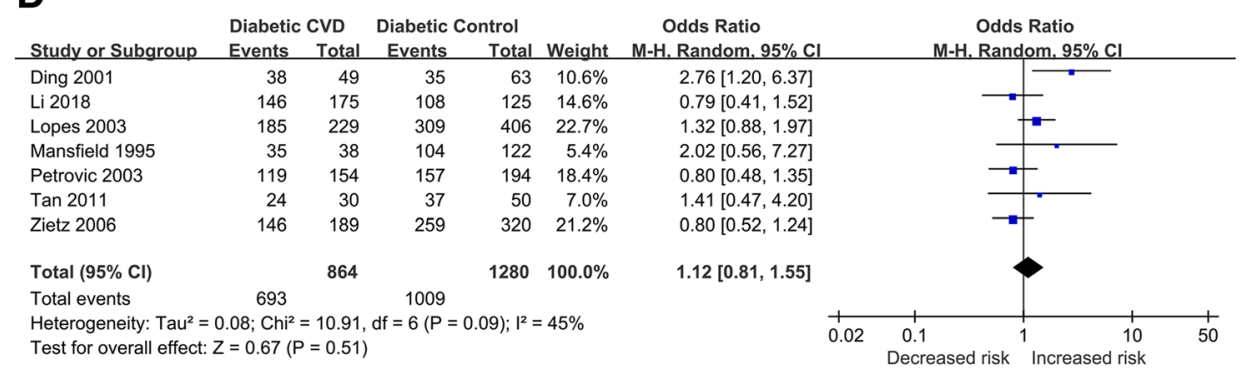

E

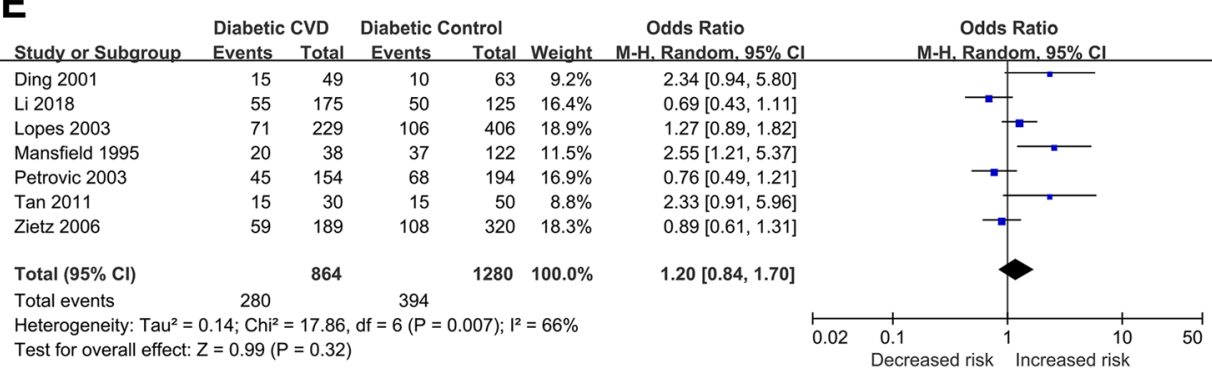

Fig. 4 Forest plots of the association between SERPINE1 rs1799889 SNP and diabetic CVD risk. (A) allelic model, (B) homozygote model, (C) heterozygote model, (D) dominant model, and (E) recessive model (CVD: cardiovascular disease) 


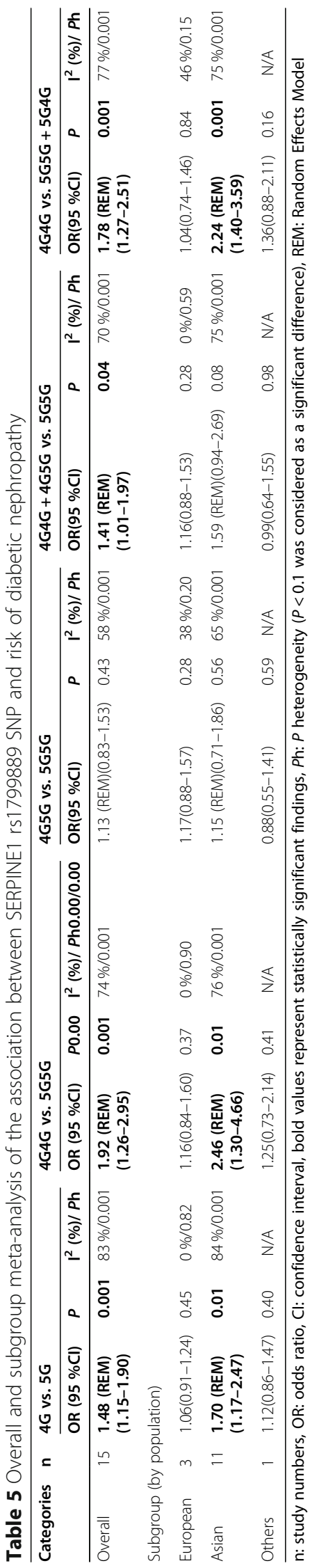




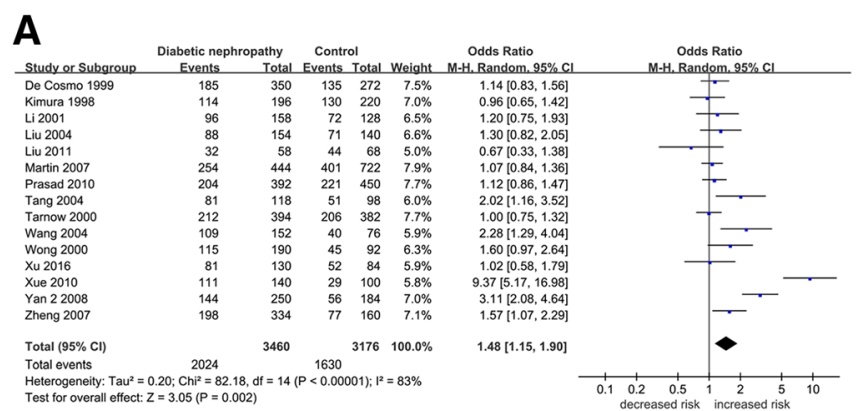

B

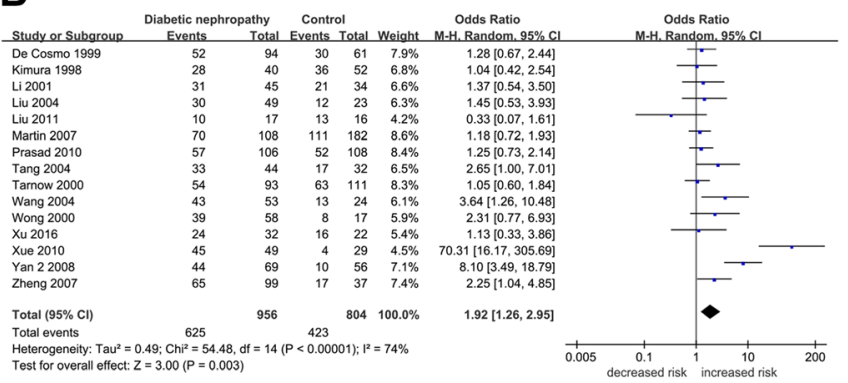

C

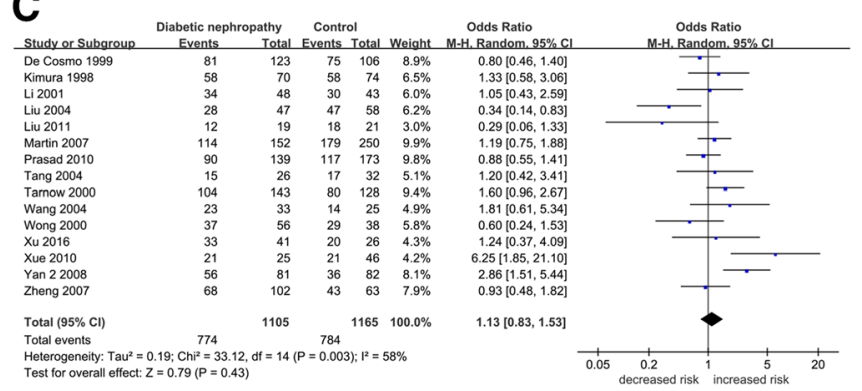

\section{D}

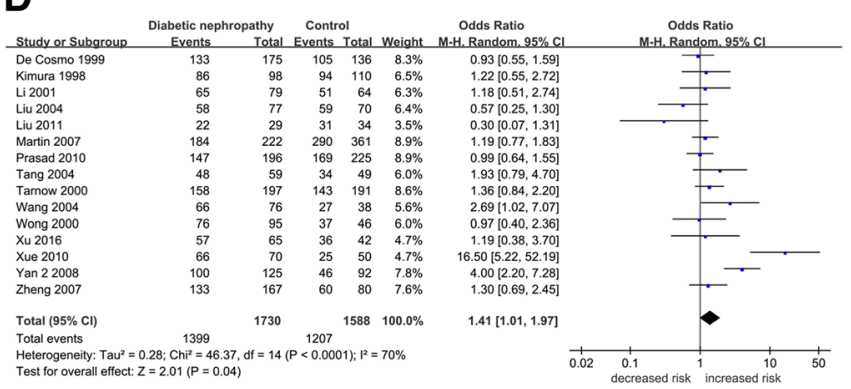

E

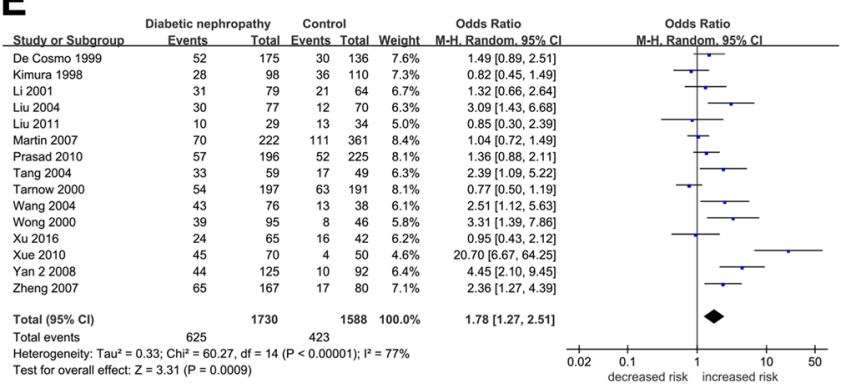

Fig. 5 Forest plots of the association between SERPINE1 rs1799889 SNP and DN risk. (A) allelic model, (B) homozygote model, (C) heterozygote model, (D) dominant model, and (E) recessive model (DN: diabetic nephropathy) 
Table 6 Publication bias assessment of this meta-analysis

\begin{tabular}{|c|c|c|c|c|}
\hline Genetic model & Egger's test & & Begg's test & \\
\hline & t-value & $p$ & t-value & $p$ \\
\hline Diabetes & & & & \\
\hline Allelic model & 2.96 & 0.01 & 2.72 & 0.01 \\
\hline Homozygote model & 2.99 & 0.01 & 2.96 & 0.001 \\
\hline Heterozygote model & 3.11 & 0.01 & 2.11 & 0.04 \\
\hline Dominant model & 2.48 & 0.02 & 1.99 & 0.05 \\
\hline Recessive model & 2.23 & 0.03 & 1.87 & 0.06 \\
\hline Diabetic retinopathy & & & & \\
\hline Allelic model & -0.98 & 0.36 & 0.00 & 1.00 \\
\hline Homozygote model & -1.88 & 0.10 & 0.36 & 0.72 \\
\hline Heterozygote model & 0.74 & 0.48 & 0.54 & 0.59 \\
\hline Dominant model & 0.04 & 0.97 & 0.00 & 1.00 \\
\hline Recessive model & -1.39 & 0.20 & 0.00 & 1.00 \\
\hline Diabetic CVD & & & & \\
\hline Allelic model & 1.88 & 0.12 & 1.20 & 0.23 \\
\hline Homozygote model & 1.49 & 0.20 & 0.60 & 0.55 \\
\hline Heterozygote model & 0.62 & 0.56 & 0.90 & 0.37 \\
\hline Dominant model & 1.13 & 0.31 & 0.90 & 0.37 \\
\hline Recessive model & 1.88 & 0.12 & 0.30 & 0.76 \\
\hline Diabetic nephropathy & & & & \\
\hline Allelic model & 1.18 & 0.09 & 1.98 & 0.05 \\
\hline Homozygote model & 1.63 & 0.13 & 1.48 & 0.14 \\
\hline $\begin{array}{l}\text { Heterozygote model } \\
\text { Dominant model }\end{array}$ & $\begin{array}{l}-0.11 \\
0.61\end{array}$ & $\begin{array}{l}0.91 \\
0.55\end{array}$ & $\begin{array}{l}0.00 \\
0.69\end{array}$ & $\begin{array}{l}1.00 \\
0.49\end{array}$ \\
\hline Recessive model & 3.05 & 0.01 & 2.18 & 0.03 \\
\hline
\end{tabular}

$P \prec 0.05$ was considered as a significant difference

et al. [22] and Lopes et al. [31] have proved the synergistic effect between the SERPINE1 4G/5G polymorphism and CVD, suggesting its potential correlation with insulin-resistance and obesity. Nevertheless, Petrovic et al. [29] found no association between this polymorphism and myocardial infarction.

Our results revealed an obvious difference in the association of the SERPINE1 rs1799889 SNP among individuals with Asian and European descent, implying that the heterogeneity is based on ethnicity. Concerning the association with diabetes risk, our results suggested that the $4 \mathrm{G}$ polymorphism is a genetic risk factor in overall populations. Moreover, after stratification by ethnicity, the results revealed a remarkable association with Asian descent, while no association was found for European diabetic populations. A previous meta-analysis showed different results [11]. Regarding the association with DR risk, our results differed from Zhang et al. [10] but were in concordance with $\mathrm{Xu}$ et al. [11]. In our analysis, we included a novel German study [36]. Additionally, both random and fixed effects model was adapted to demonstrate less bias and to confirm a robust conclusion. Since our meta-analysis has included recent published studies and larger sample sizes, we suppose it could provide better reliability. We hypothesize that these factors might contribute to the disparities with other studies. Concerning the association with diabetic CVD risk, our results coincided with a previous analysis [11], which proved no significant association despite the inclusion of recent studies [12]. This result was to some extent disparate from other analyses concerning PAI-1 polymorphisms in atherosclerotic diseases [70] and suggests that the underlying mechanism for the SERPINE1 4G/5G polymorphism might be conducted through different pathways in diabetic CVD. Concerning the association with DN risk, our results indicated a strong linkage between SERPINE1 4G polymorphism and DN risk in the overall and Asian populations. This is consistent with former studies $[25,71]$ and further implies that heterogeneity is affected by ethnicity. Moreover, insufficient genetic data in mix ethnicities could limit the possibility of further discussion regarding this population, which to a considerable extent could alter the overall analyses. To our knowledge, the current meta-analysis includes the largest sample size to date with the most extensive case-control studies, and demonstrates an ethnicity-based evaluation for different results among studies. The association with ischemic stroke in the diabetic population was not further evaluated in the present study owing to limitations of available trails, but would be an important topic for consideration in future studies concerning diabetic atherothrombotic complications. In addition, future investigations are also warranted to discover the possible functions of other SERPINE1 gene polymorphisms in DM and its complications.

Since our meta-analysis was conducted with stratified ethnicity, the origins of heterogeneity must be given thorough discussion. In our analysis, heterogeneity was revealed among people of Asian descent both in the CVD and DN subgroups. We speculate that the sources of heterogeneity in studies might include age and gender proportion, ethnic traits, environmental factors, medication status, health care quality and cultural differences. A meta-regression analysis was done by study type, published years, age, gender, ethnicity, sample sizes, and outcomes. However, the results did not indicate the sources of heterogeneity, since all the $p$ values calculated above were larger than 0.05 . As we speculated, meta-regression is usually conducted in studies with larger sample sizes and study sub-groups, whose effect might be restrained in this case. Moreover, the gene-gene and geneenvironmental interactions might also trigger the heterogeneity of genetic effects between individual studies.

There were several limitations included in our metaanalysis: (1) insufficient genotyping data of SERPINE1 
rs1799889 SNP in mix ethnicity, which limited the possibility to further discussions regarding this population, and (2) potential heterogeneity of study variables, such as the biological parameters of study subjects, clinical history, medication compliance, other diabetic complications, etc. and (3) the Begg's and Egger's test have given some potential publication bias, indicating the importance of a well-matched case-control study population. (4) Sample size is another limitation, some of the original studies analyzed presented relatively small control groups, and the minor allele frequency (G or 5G; MAF) of the control populations analyzed are heterogeneous, between 34.2 and $71 \%$, including among studies in the same ethnicity group and also in the same study among different analyzed groups. (5) Insufficiency of original studies of type $1 \mathrm{DM}$ has restrained a further subgroup analysis concerning the classification of DM.

\section{Conclusions}

Collectively, our meta-analysis demonstrates that the SERPINE1 rs1799889 4G polymorphism may outstand for serving as a genetic synergistic factor in overall DM populations, and overall DN populations. Moreover, it can be positively associated with increased DM and DN risks for individuals with Asian descent. The association of SERPINE1 rs1799889 polymorphisms and DR or diabetic CVD risks was not revealed by our meta-analysis. However, future studies with multiple ethnicities and rigorous designs are still in-need to confirm our conclusions.

\begin{abstract}
Abbreviations
DM: diabetes mellitus; SERPINE1: serine protease inhibitor-1; SNP: single nucleotide polymorphism; PAl-1: plasminogen activator inhibitor-1; PRISMA: Preferred Reporting Items for Systematic Reviews and Meta-Analyses; DR: diabetic retinopathy; DN: diabetic nephropathy; CAD/CHD: coronary artery/ heart disease; CVD: cardiovascular disease; OR: odds ratio; Cl: confidence interval; DCCT: Diabetes Control and Complications Trial; EDIC: Epidemiology of Diabetes Interventions and Complications; GWAS: Genome Wide Association Studies; tPA: tissue-type plasminogen activator
\end{abstract}

\section{Supplementary information}

The online version contains supplementary material available at https://doi. org/10.1186/s12902-021-00837-z.

Additional file 1: Supplementary Table 1. Newcastle-Ottawa scale

(NOS) for assessing quality of observational studies.

Additional file 2: Supplementary Table 2. Search strategy for PubMed.

Additional file 3: Supplementary Fig. 1. Cumulative meta-analysis of the chronologic integration between SERPINE1 rs1799889 SNP and diabetes risk. (A) allelic model, (B) homozygote model, (C) heterozygote model, (D) dominant model, and (E) recessive model.

Additional file 4: Supplementary Fig. 2. Begg's funnel plot of bias for studies of the association between SERPINE1 rs1799889 SNP and diabetes risk. (A) allelic model, (B) homozygote model, (C) heterozygote model, (D) dominant model, and (E) recessive model.

Additional file 5: Supplementary Fig. 3. Begg's funnel plot of bias for studies of the association between SERPINE1 rs1799889 SNP and DR risk.
(A) allelic model, (B) homozygote model, (C) heterozygote model, (D) dominant model, and $(\mathbf{E})$ recessive model.

Additional file 6: Supplementary Fig. 4. Begg's funnel plot of bias for studies of the association between SERPINE1 rs1799889 SNP and CVD risk. (A) allelic model, (B) homozygote model, (C) heterozygote model, (D) dominant model, and (E) recessive model.

Additional file 7: Supplementary Fig. 5. Begg's funnel plot of bias for studies of the association between SERPINE1 rs1799889 SNP and DN risk. (A) allelic model, (B) homozygote model, (C) heterozygote model, (D) dominant model, and $(\mathbf{E})$ recessive model.

\section{Acknowledgements}

The authors gratefully acknowledge the financial supports by Tianjin Chest Hospital Labor Union (HL Cong's model worker innovation studio), and Tianjin Eye Institute, Tianjin Key Lab of Ophthalmology and Visual Science for their linguistic assistance during the preparation of this manuscript.

\section{Authors' contributions}

H.L.C. and Y.W. designed the study. J.Y.C. and C.N.Z. prepared the original manuscript, performed statistical analysis and participated in most of the study steps. Z.Q.W. constructed the manuscript revision. Z.Q.W. and R.L. prepared the manuscript and assisted in the study processes. W.J.W., K.H. and M.A. assisted in the data collection, and helped in the interpretation of the study. All authors read and approved the final manuscript.

\section{Funding}

The present study was funded by National Natural Science Foundation of China (No. 81670884 and No. 81873684) and Youth Program of National Natural Science Foundation of China (No. 81900828). The funding body of the study (No. 81670884, 81873684 and 81900828 ) had no role in the design of the study and collection, analysis, and interpretation of data and in writing the manuscript. The corresponding author (Hongliang Cong \& Yan Wang) had full access to all the data and final responsibility for the decision to submit for publication.

\section{Availability of data and materials}

The data analysed during the current meta-analysis is included in this published article and its supplementary information files, and other relevant data is available from the corresponding author on reasonable request.

\section{Declarations}

Ethics approval and consent to participate Not applicable.

\section{Consent for publication}

Not applicable.

\section{Competing interests}

The authors declare that they have no competing interests.

\section{Author details}

'School of Medicine, NanKai University, Weijin Road No. 94, Nankai District, 300071 Tianjin, China. ${ }^{2}$ Tianjin Key Lab of Ophthalmology and Visual Science, Tianjin Eye Institute, Tianjin Eye Hospital, Gansu Road No. 4, Heping District, 300020 Tianjin, China. ${ }^{3}$ Department of Cardiology, Tianjin Chest Hospital, Taierzhuang south Road No. 291, Jinnan District, 300350 Tianjin, China. ${ }^{4}$ Department of Optometry, Shenyang Eye Institute, The 4th People's Hospital of Shenyang, No 20. Huanghe South Avenue, Huanggu District, 110031 Shenyang, Liaoning, China. ${ }^{5}$ Tianjin GongAn Hospital, Nanjing Road No. 78, Heping District, 300042 Tianjin, China.

Received: 25 March 2020 Accepted: 10 August 2021

Published online: 30 September 2021

References

1. Castañeda-Delgado JE. Diabetic complication could get a gene therapy boost. Gene Ther. 2018;25(6):401. 
2. Zheng Y, Ley SH, Hu FB. Global aetiology and epidemiology of type 2 diabetes mellitus and its complications. Nat Rev Endocrinol. 2018;14(2): 88-98.

3. Kautzky-Willer A, Harreiter J, Pacini G. Sex and Gender Differences in Risk, Pathophysiology and Complications of Type 2 Diabetes Mellitus. Endocr Rev. 2016:37(3):278-316.

4. Papatheodorou K, Banach M, Bekiari E, Rizzo M, Edmonds M. Complications of Diabetes 2017. J Diabetes Res. 2018;2018:3086167.

5. Stumvoll M, Goldstein BJ, van Haeften TW. Type 2 diabetes: principles of pathogenesis and therapy. Lancet. 2005;365(9467):1333-46.

6. Mutch NJ, Thomas L, Moore NR, Lisiak KM, Booth NA. TAFla. PAl-1 and alpha-antiplasmin: complementary roles in regulating lysis of thrombi and plasma clots. J Thromb Haemost. 2007:5(4):812-7.

7. Westrick RJ, Eitzman DT. Plasminogen activator inhibitor-1 in vascular thrombosis. Curr Drug Targets. 2007;8(9):966-1002.

8. Festa A, D'Agostino R, Mykkänen $L$, et al. Relative contribution of insulin and its precursors to fibrinogen and PAI-1 in a large population with different states of glucose tolerance. The Insulin Resistance Atherosclerosis Study (IRAS). Arterioscler Thromb Vasc Biol. 1999;19(3):562-8.

9. Eriksson P, Kallin B, van 't Hooft FM, Båvenholm P, Hamsten A. Allele-specific increase in basal transcription of the plasminogen-activator inhibitor 1 gene is associated with myocardial infarction. Proc Natl Acad Sci U S A. 1995; 92(6):1851-5

10. Zhang T, Pang C, Li N, Zhou E, Zhao K. Plasminogen activator inhibitor-1 4G/5G polymorphism and retinopathy risk in type 2 diabetes: a metaanalysis. BMC Med. 2013;11:1.

11. Xu K, Liu X, Yang F, et al. PAl-1 -675 4G/5G polymorphism in association with diabetes and diabetic complications susceptibility: a meta-analysis study. PLoS One. 2013;8(11):e79150.

12. Li G, Liu Y, Li X, et al. Association of PAl-1 4G/5G Polymorphism with Ischemic Stroke in Chinese Patients with Type 2 Diabetes Mellitus. Genet Test Mol Biomarkers. 2018;22(9):554-60.

13. Xu F, Liu H, Sun Y. Association of plasminogen activator inhibitor-1 gene polymorphism and type 2 diabetic nephropathy. Ren Fail. 2016;38:157-62.

14. Moher D, Liberati A, Tetzlaff J, Altman DG. Preferred reporting items for systematic reviews and meta-analyses: the PRISMA statement. Ann Intern Med. 2009;151(4):264-9, W64.

15. Stang A: Critical evaluation of the Newcastle-Ottawa scale for the assessment of the quality of nonrandomized studies in meta-analyses. Eur J Epidemiol 2010, 25(9):603-605.10.1007/s10654-010-9491-z.

16. Robins J, Greenland S, Breslow NE. A general estimator for the variance of the Mantel-Haenszel odds ratio. Am J Epidemiol. 1986;124(5):719-23.

17. Egger M, Smith GD, Phillips AN. Meta-analysis: principles and procedures. BMJ. 1997;315(7121):1533-7.

18. DerSimonian R, Laird N. Meta-analysis in clinical trials. Control Clin Trials. 1986;7(3):177-88.

19. Higgins JP, Thompson SG. Quantifying heterogeneity in a meta-analysis. Stat Med. 2002;21(11):1539-58.

20. Egger M, Davey SG, Schneider M, Minder C. Bias in meta-analysis detected by a simple, graphical test. BMJ. 1997;315(7109):629-34.

21. Begg CB, Mazumdar M. Operating characteristics of a rank correlation test for publication bias. Biometrics. 1994;50(4):1088-101.

22. Mansfield MW, Stickland MH, Grant PJ. Plasminogen activator inhibitor(PAl-1) promoter polymorphism and coronary artery disease in non-insulindependent diabetes. Thromb Haemost. 1995;74(4):1032-4.

23. Nagi DK, McCormack L, Mohamed-Ali V, Yudkin JS, Knowler WC, Grant PJ. Diabetic retinopathy, promoter (4G/5G) polymorphism of PAl-1 gene, and PAI-1 activity in Pima Indians with type 2 diabetes. Diabetes Care. 1997; 20(8):1304-9.

24. Broch M, Gutierrez C, Aguilar C, Simon I, Richart C, Vendrell J. Genetic variation in promoter $(4 \mathrm{G} / 5 \mathrm{G})$ of plasminogen activator inhibitor 1 gene in type 2 diabetes. Absence of relationship with microangiopathy. Diabetes Care. 1998:21:463.

25. Kimura H, Gejyo F, Suzuki Y, Suzuki S, Miyazaki R, Arakawa M. Polymorphisms of angiotensin converting enzyme and plasminogen activator inhibitor-1 genes in diabetes and macroangiopathy1. Kidney Int. 1998;54:1659-69.

26. De Cosmo S, Margaglione M, Tassi V, Garrubba M, Thomas S, Olivetti C, et al. ACE, PAI-1, decorin and Werner helicase genes are not associated with the development of renal disease in European patients with type 1 diabetes. Diabetes Metab Res Rev. 1999;15:247-53.
27. Wong TY, Poon P, Szeto CC, Chan JC, Li PK. Association of plasminogen activator inhibitor-1 4G/4G genotype and type 2 diabetic nephropathy in Chinese patients. Kidney Int. 2000;57:632-8.

28. Ding GX, SHEN J, CHEN JW. Relationship between Polymorphisms of PAl-1 Gene, ATN Gene and Coronary Heart Disease in Type 2-DM: Report of 281 Cases. Acta Nanjing Med Univ. 2001;21:95-8.

29. Petrovic D, Globocnik-Petrovic M, Peterlin B. 4G4G genotype of PAl-1 gene promoter polymorphism is not associated with myocardial infarction in Caucasians with type-2 diabetes. Cardiology. 2003;100(3):157-8.

30. Globocnik-Petrovic M, Hawlina M, Peterlin B, Petrovic D. Insertion/deletion plasminogen activator inhibitor 1 and insertion/deletion angiotensinconverting enzyme gene polymorphisms in diabetic retinopathy in type 2 diabetes. Ophthalmologica. 2003;217:219-24.

31. Lopes C, Dina C, Durand E, Froguel P. PAl-1 polymorphisms modulate phenotypes associated with the metabolic syndrome in obese and diabetic Caucasian population. Diabetologia. 2003;46(9):1284-90.

32. Liu SG, Xue YM, Yang GC, He FY, Zhao XS. Relationship between plasminogen activator inhibitor-1 gene $4 \mathrm{G} / 5 \mathrm{G}$ polymorphism and type 2 diabetic nephropathy in Chinese Han patients in Guangdong Province. Journal of first military medical university. 2004;24:904-7.

33. Pan SZ, Yan XF, Lin JY, Yang LY. Association of ACE and PAl-1 gene polymorphisms with plasma PAl-1 level in type 2 diabetic patients. Chinese journal endocrinol metabolics. 2004;20:451-2.

34. Santos KG, Tschiedel B, Schneider J, Souto K, Roisenberg I. Diabetic retinopathy in Euro-Brazilian type 2 diabetic patients: relationship with polymorphisms in the aldose reductase, the plasminogen activator inhibitor-1 and the methylenetetrahydrofolate reductase genes. Diabetes Res Clin Pract. 2003;61(2):133-6.

35. Meigs JB, Dupuis J, Liu C, O'Donnell CJ, Fox CS, Kathiresan S, et al. PAI-1 Gene $4 \mathrm{G} / 5 \mathrm{G}$ polymorphism and risk of type 2 diabetes in a populationbased sample. Obesity (Silver Spring). 2006;14:753-8.

36. Zietz B, Leonhardt K, Schäffler A. [Candidate genes and polymorphism analysis in type 2 diabetes mellitus]. Med Klin (Munich). 2006;101(8):605-16.

37. Saely $\mathrm{CH}$, Muendlein A, Vonbank A, et al. Type 2 diabetes significantly modulates the cardiovascular risk conferred by the PAI-1 - $6754 \mathrm{G} / 5 \mathrm{G}$ polymorphism in angiographied coronary patients. Clin Chim Acta. 2008; 396(1-2):18-22.

38. Yan XF, PAN SZ, Yan SJ, Zhang SQ. Relationship between plasminogen activator inhibitor 1 gene polymorphism and the level of endothelium-dependent vasodilatation in patients with type 2 diabetes. Clinical Medicine of China. 2008;24:708-10.

39. Li P, Song GY. The study of plasma plasminogen activator inhibitor type-1 (PAI-1)activity and the polymorphism of PAI-1 gene in the NGT first degree relatives of type 2 diabetes. Hebei Medical University 2004:1-37.

40. Ezzidi I, Mtiraoui N, Chaieb M, Kacem M, Mahjoub T, Almawi WY. Diabetic retinopathy, PAI-1 4G/5G and - 844G/A polymorphisms, and changes in circulating PAl-1 levels in Tunisian type 2 diabetes patients. Diabetes Metab. 2009;35(3):214-9.

41. Al-Hamodi Z, Saif-Ali R, Ismail IS, Ahmed KA, Muniandy S. Effect of plasminogen activator inhibitor-1 and tissue plasminogen activator polymorphisms on susceptibility to type 2 diabetes in Malaysian subjects. J Biomed Biotechnol. 2012. 2012: 234937.

42. Weng SC, Shu KH, Tarng DC, Wu MJ, Chen CH, Yu TM, et al. Gene polymorphisms are associated with posttransplantation diabetes mellitus among Taiwanese renal transplant recipients. Transplant Proc. 2012;44:667-71.

43. Yan XF, Pan SZ, Yang LY, Huang LN, Zhao SH. Correlation Analysis of Polymorphisms of Angiotensin Converting Enzyme Gene, Plasminogen Activator Inhibitor-1 Gene and Nephropathy in Type 2 Diabetes. China Med. 2008:3:81-3.

44. Shu YT, Tian JL. The association study of PAl-1 gene polymorphism and diabetic CAD. Clin Res. 2011;6:86-8.

45. Murata M, Maruyama T, Suzuki Y, Saruta T, Ikeda Y. Paraoxonase $1 \mathrm{Gln} /$ Arg polymorphism is associated with the risk of microangiopathy in Type 2 diabetes mellitus. Diabet Med. 2004:21:837-44.

46. Tarnow L, Stehouwer CD, Emeis JJ, Poirier O, Cambien F, Hansen BV, Parving HH. Plasminogen activator inhibitor-1 and apolipoprotein E gene polymorphisms and diabetic angiopathy. Nephrol Dial Transplant. 2000;15:625-30.

47. Martin RJ, Savage DA, Patterson CC, Brady HR, Maxwell AP. Common polymorphisms of the PAl1 gene do not play a major role in the development of diabetic nephropathy in Type 1 diabetes. Diabet Med. 2007;24:259-65. 
48. Prasad P, Tiwari AK, Kumar KM, Ammini AC, Gupta A, Gupta R, Thelma BK. Association analysis of ADPRT1, AKR1B1, RAGE, GFPT2 and PAl-1 gene polymorphisms with chronic renal insufficiency among Asian Indians with type-2 diabetes. BMC Med Genet. 2010;11:52.

49. Li CG, Dong YH, Wang HY. Association of plasminogen activator inhibitor type-1 4G/5G polymorphism and type 2 diabetic with nephropathy. Circulation. 2001;9:333-6.

50. Wang $L$, Liu $Y$. The relationship between polymorphisms of PAl-1 gene, PAl1 antigen in plasma with diabetes nephropathy. Jilin University; 2004: p. 1-52.

51. Tang KX. The association between gene expression of PAl-1 in adipose tissue of type 2 diabetes and vascular disease. Clin Chim Acta. 2004;15:1126-8.

52. Zheng TS, Liu LM, Zhou WR. Correlation of plasminogen activator inhibitor-l gene polymorphism with type 2 diabetic nephropathy in Chinese. J Shanghai Jiaotong University (Med Sci). 2007;27:774-6.

53. Xue J, Tian GS, Shi FH, Ge B. Polymorphisms of plasminogen activator inhibitor-l genes in type 2 diabetes with nephropathy in Han in Baotou. Chin Med J Metall Ind. 2010;27:373-5.

54. Liu MY, Yang ZS, Shen LY, Sun SY, Li H. Association of plasminogen activator inhibitor-1 4G/5G polymorphism and type 2 diabetes with early nephropathy. Acta Acad Med Qingdao Univ. 2006:47:31-2.

55. Pierce $M$, Keen $H$, Bradley $C$. Risk of diabetes in offspring of parents with non-insulin-dependent diabetes. Diabet Med. 1995;12(1):6-13.

56. Kaprio J, Tuomilehto J, Koskenvuo M, et al. Concordance for type 1 (insulindependent) and type 2 (non-insulin-dependent) diabetes mellitus in a population-based cohort of twins in Finland. Diabetologia. 1992;35(11):1060-7.

57. Effect of intensive diabetes treatment on the development. and progression of long-term complications in adolescents with insulin-dependent diabetes mellitus: Diabetes Control and Complications Trial. Diabetes Control and Complications Trial Research Group. J Pediatr. 1994;125(2):177-88.

58. Intensive blood-glucose. control with sulphonylureas or insulin compared with conventional treatment and risk of complications in patients with type 2 diabetes (UKPDS 33). UK Prospective Diabetes Study (UKPDS) Group. Lancet. 1998;352(9131):837-53.

59. Nyaga DM, Vickers MH, Jefferies C, Perry JK, O'Sullivan JM. The genetic architecture of type 1 diabetes mellitus. Mol Cell Endocrinol. 2018;477:70-80.

60. Ahmad S, Ahluwalia TS. Editorial. The Role of Genetic and Lifestyle Factors in Metabolic Diseases. Front Endocrinol (Lausanne). 2019;10:475.

61. Flannick J, Mercader JM, Fuchsberger C, et al. Exome sequencing of 20,791 cases of type 2 diabetes and 24,440 controls. Nature. 2019:570(7759):71-6.

62. Ahluwalia TS, Kilpeläinen TO, Singh S, Rossing P. Editorial: Novel Biomarkers for Type 2 Diabetes. Front Endocrinol (Lausanne). 2019;10:649.

63. Cesari M, Pahor M, Incalzi RA. Plasminogen activator inhibitor-1 (PAI-1): a key factor linking fibrinolysis and age-related subclinical and clinical conditions. Cardiovasc Ther. 2010;28(5):e72-91.

64. Hamsten $A$, de Faire $U$, Walldius $G$, et al. Plasminogen activator inhibitor in plasma: risk factor for recurrent myocardial infarction. Lancet. 1987;2(8549):3-9.

65. Kohler HP, Grant PJ. Plasminogen-activator inhibitor type 1 and coronary artery disease. N Engl J Med. 2000;342(24):1792-801.

66. Festa A, D'Agostino R, Tracy RP, Haffner SM. Elevated levels of acute-phase proteins and plasminogen activator inhibitor-1 predict the development of type 2 diabetes: the insulin resistance atherosclerosis study. Diabetes. 2002; 51(4):1131-7.

67. Festa A, Williams K, Tracy RP, Wagenknecht LE, Haffner SM. Progression of plasminogen activator inhibitor-1 and fibrinogen levels in relation to incident type 2 diabetes. Circulation. 2006;113(14):1753-9.

68. Huang J, Sabater-Lleal M, Asselbergs FW, et al. Genome-wide association study for circulating levels of PAl-1 provides novel insights into its regulation. Blood. 2012;120(24):4873-81.

69. Rosito GA, D'Agostino RB, Massaro J, et al. Association between obesity and a prothrombotic state: the Framingham Offspring Study. Thromb Haemost. 2004;91(4):683-9.

70. Liu Y, Cheng J, Guo X, Mo J, Gao B, Zhou H, et al. The roles of PAl-1 gene polymorphisms in atherosclerotic diseases: A systematic review and metaanalysis involving 149,908 subjects. Gene. 2018;673:167-73.

71. Gao WF, Guo YB, Bai Y, Ding XY, Yan YJ, Wu ZQ. Association between PAl-1 4G/5G polymorphism and diabetic nephropathy: a meta-analysis in the Chinese population. Int Urol Nephrol. 2016;48:1483-9.

\section{Publisher's Note}

Springer Nature remains neutral with regard to jurisdictional claims in published maps and institutional affiliations.

Ready to submit your research? Choose BMC and benefit from:

- fast, convenient online submission

- thorough peer review by experienced researchers in your field

- rapid publication on acceptance

- support for research data, including large and complex data types

- gold Open Access which fosters wider collaboration and increased citations

- maximum visibility for your research: over $100 \mathrm{M}$ website views per year

At BMC, research is always in progress.

Learn more biomedcentral.com/submissions 